ENTREPRENEURSHIP AND SUSTAINABILITY ISSUES

ISSN 2345-0282 (online) http://jssidoi.org/jesi/

2020 Volume 8 Number 2 (December)

http://doi.org/10.9770/jesi.2020.8.2(30)

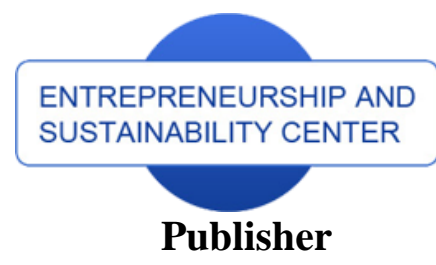

http://jssidoi.org/esc/home
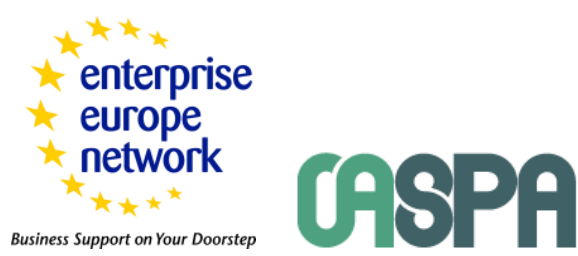

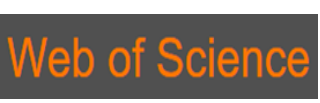

1) Clarivate

Analytics

\title{
LEVEL OF ADMINISTRATIVE EMPOWERMENT AT PRIVATE INSTITUTION AND ITS IMPACT ON INSTITUTIONAL PERFORMANCE: A CASE STUDY
}

\author{
Ahmad Ismail Al Maani ${ }^{1}$, Ahmad Al Adwan ${ }^{2}$, Ahmad Yousef Areiqat ${ }^{3}$, Ahmad M.A. Zamil ${ }^{4}$, \\ Anas A. Salameh ${ }^{5}$ \\ ${ }^{1}$ Department of Higher Education, Modern College of Business \& Science, Oman \\ ${ }^{2}$ Marketing Department, Business School, Al-Ahliyya Amman University, Jordan \\ ${ }^{3}$ Department of Business Administration, Business School, Al-Ahliyya Amman University, Jordan \\ ${ }^{4}$ Department of Marketing, College of Business Administration, Prince Sattam bin Abdulaziz University, Saudi Arabia \\ ${ }^{5}$ Department of Management Information Systems, College of Business Administration, Prince Sattam bin Abdulaziz \\ University, Saudi Arabia \\ E-mails: ${ }^{1}$ ahmed.almaani@mcbs.edu.om ; ${ }^{2}$ a.aladwan@ammanu.edu.jo; ${ }_{-}^{3}$ ahmadareiqat@ammanu.edu.jo; \\ ${ }^{3}$ am.zamil@psau.edu.sa; ${ }^{4}$ a.salameh@psau.edu.sa
}

Received 25 May 2020; accepted 31 August 2020; published 30 December 2020

\begin{abstract}
The study aims to scrutinize the level of administrative empowerment involving its dimensions (delegating powers/devolution of authorities, independence, learning, and training) on institutional performance (commitment to quality standards, achieving the goals, and staff performance) of Al-Ahliyya Amman University (AAU). The researchers applied the descriptive-analytical method by developing a questionnaire that was distributed among a simple random sample consisting of (200) members, and the data were analyzed, and the assumptions were tested using the statistical program (SPSS v20). The findings of the study revealed that there was a statistically significant impact of the level of administrative empowerment including its combined dimensions on the institutional performance at AAU. Furthermore, there was a statistically significant impact of the level of administrative empowerment involving its combined dimensions on the commitment to quality standards at AAU. The researchers recommend adopting a strategy that achieves the implementation of modern management concepts at AAU such as career empowerment, Total Quality Management (TQM), and teamwork, as well as focusing on the qualification of AAU staff. Such training will help workers practice career empowerment through the implementation of specific action plans for developmental purposes, the development of annual training plans, the use of effective means such as lectures, and motivating employees to participate in training courses and activities.
\end{abstract}

Keywords: administrative empowerment; devolution of authorities; job satisfaction; decentralization; institutional performance; teamwork

Reference to this paper should be made as follows: Al Maani, A.I., Ahmad Al Adwan, A., Areiqat, A.Y., Zamil, A.M.A.Salameh, A.A. 2020. Level of administrative empowerment at private institution and its impact on institutional performance: a case study. Entrepreneurship and Sustainability Issues, 8(2), 500-511. http://doi.org/10.9770/jesi.2020.8.2(30)

JEL Classifications: J28, L25, L15, D83, M53, D83 


\section{ENTREPRENEURSHIP AND SUSTAINABILITY ISSUES}

ISSN 2345-0282 (online) http://jssidoi.org/jesi/

2020 Volume 8 Number 2 (December)

http://doi.org/10.9770/jesi.2020.8.2(30)

Make your research more visible, join the Twitter account of ENTREPRENEURSHIP AND SUSTAINABILITY ISSUES: @Entrepr69728810

\section{Introduction}

Administrative empowerment is a contemporary concept that seeks to raise and develop individuals' capacities and skills to solve their managerial problems and offer them opportunities to initiate and challenge; by encouraging them to shoulder responsibilities for the decision-making, cooperation, and participation to achieve the desired goals. Moreover, administrative empowerment is considered an effective strategy that enhances managers' performance, as they have a high level of capacities and skills in addition to job satisfaction towards their organizations and careers. This will be maintained by providing them with full freedom at work to think and act independently under the umbrella of administrative decentralization methodology (Khalayleh, Masa'deh \&AlLozi, 2017). Administrative empowerment is based on building-up trust between the workers and their leadership and encouraging them to participate in the decision-making process, in addition to breaking administrative and organizational barriers between the leadership and the staff. It also incorporates offering workers the freedom to act and enhances their participation in decision-making, and thus it guarantees the quality of the leaders' performance in administrative implementation and creativity at the same time. The typical result of administrative empowerment is represented in helping the administrative leadership obtain the uttermost benefit from the available human and material resources in their institutions to accomplish the desired goals of their organization and thus the outcome will be a higher level of job satisfaction. (Al-Omari et al, 2020). Since organizations are seeking to keep pace with the trend towards growth and development, they have to respond to the requirements for applying the principles of open management, decentralization, the delegation of powers/ devolution of authorities besides participating in decision-making to enhance the level of knowledge, skill, and administrative professionalism and improve institutional performance. Effective performance is a part and parcel of the enterprise system and is one of the most important programs that aim to achieve the goals of the organization, and it is also very essential to improve and enhance performance and upgrade the level of workers. (Uddin, 2017). Decentralization is a modern reform process that is embraced by many sectors with different types of business, and modern companies have adopted a decentralized hierarchy, which is expected to raise the level of creativity among employees. However, the tendency towards decentralization must be properly applied, restrictive, and a limited process. Excessive decentralization may create a state of chaos in the company (Thomas \& Priyanka, 2014). In light of the importance of institutional performance and the role of administrative empowerment in achieving necessary skills to improve employees' performance and the devolution of authorities that enable them to solve problems practically and efficiently, this study seeks to identify the level of administrative empowerment in institutions and detect its impact on institutional performance at the AAU. The gap in previous researches is the impact of administrative empowerment on institutional performance. Administrative empowerment concerns raising and developing individuals' capacities and skills. Moreover, it can be employed by applying modern management concepts such as career empowerment, (TQM) and teamwork, as well as focusing on the staff qualification. One of the biggest challenges that most of the firm's face is the centralization of powers which delay and slowing down organizations from achieving its tasks, activities, and interest. Administrative empowerment is a very promising area for most of the organization. Thus, to fill this gap, this research aims to determine the impact of administrative empowerment including its dimensions (delegating powers/devolution of authorities, independence, learning, and training) on institutional performance in the AAU into the Jordanian context. 


\section{ENTREPRENEURSHIP AND SUSTAINABILITY ISSUES}

ISSN 2345-0282 (online) http://jssidoi.org/jesi/

2020 Volume 8 Number 2 (December)

http://doi.org/10.9770/jesi.2020.8.2(30)

Make your research more visible, join the Twitter account of ENTREPRENEURSHIP AND SUSTAINABILITY ISSUES: @Entrepr69728810

\section{Problem and Questions of the Study}

Empowering workers brings many benefits to the organization as it works to develop managers 'way of thinking, develop their creative capabilities, and allow more time for them to focus on strategic matters, develop visions, formulate long-term mission and goals, and draw long-term plans (Al-Maghribi, 2001). To the essential impact of applying the strategy of empowering workers to the success of the organization, because empowerment is an inevitable response to achieving the comprehensive quality requirements. The researchers believe that one of the phenomena of the administrative problems is the tendency of academic leaders in universities to concentrate power and not delegate it to their subordinates. Which causes a low spirit of enthusiasm and satisfaction among workers and thus, contributes to weakening the institutional performance. The phenomenon of centralization of powers or authorities among senior officials is considered one of the most important administrative problems facing institutions, as it leads to the sluggish implementation of organizations' tasks and activities. This phenomenon also entails paying more attention and preoccupation to routine work rather than the important administrative work involving basic tasks of the departments and the leadership such as planning, development, monitoring the progress of the institution, and policymaking. The administrative empowerment process is an inevitable action that is performed to maintain smooth and continuous implementation of various procedures and work practices in administrative units. Also, administrative empowerment allows senior management to make better use of its time rather than being engaged in routine work, and it also contributes effectively to the process of developing and improving the decision-making styles. The problem of the study lies in the fact that many institutions in Jordan are still so dependent on centralization, as they do not enable workers to perform administrative tasks, and not allowed to take part in decision-making despite the recommendations of many studies such as (Radhy, 2010, Al-Ajrafi, 2017, Al-Suhimat, 2016) to focus on the importance of administrative empowerment in improving creativity, achieving job satisfaction, and organizational creativeness in various institutions. The research problem is mainly focused on the phenomenon of the inclination of administrative leadership in institutions towards the centralization of their authorities rather than delegating power to their subordinates. Such tendency has some negative effects facing service institutions, and this is reflected in employees' enthusiasm to work sincerely and reduces the degree of job satisfaction among workers, and thus, leading to poor institutional performance. This study has been conducted to detect the degree of administrative empowerment of managers involving (delegating powers/devolution of authorities, independence, learning, and training) at the AAU. Moreover, the researchers aim to address the level of institutional performance including (Commitment to quality standards, achieving the goals, and staff performance) at the AAU. The study also aims to determine if there is an impact of administrative empowerment on institutional performance at AAU and identify if there are any significant statistical differences in the level of administrative empowerment on institutional performance AAU that could be attributed to demographic characteristics.

\section{Significance of the study}

The significance of the study is attributed to the importance of improving the level of performance in AAU through ascertaining the level of administrative empowerment and explaining its impact on the competency of institutional performance. 
ENTREPRENEURSHIP AND SUSTAINABILITY ISSUES

ISSN 2345-0282 (online) http://jssidoi.org/jesi/

2020 Volume 8 Number 2 (December)

http://doi.org/10.9770/jesi.2020.8.2(30)

Make your research more visible, join the Twitter account of ENTREPRENEURSHIP AND SUSTAINABILITY ISSUES: @Entrepr69728810

\section{Objectives of the study}

This study aims to detect the importance of administrative empowerment and its impact on the institutional performance of the AAU, including the following targets:

1- Identify the reality of the level of administrative empowerment and institutional performance at AAU.

2- Reaching results and recommendations that contribute to achieving and distinguishing institutional performance by improving the level of administrative empowerment

3- Analyzing the impact of administrative empowerment on institutional performance at the AAU.

\section{Procedural Definitions of the study terminology}

Administrative empowerment is defined as "the process of offering individuals greater authority to experience monitoring, shoulder responsibility, and invest their capacities, by motivating and encouraging them to make decisions and take personal responsibility to develop the way through which they perform their work and tasks by devolution of authorities to empower them in taking decisions at the lowest level (Al-Abdullah, 2018:16). Administrative empowerment is also represented in "Paying more attention to workers by expanding their authorities or influence, enriching the amount of information given to them, increasing opportunities given to them to take initiatives and make decisions and confront problems that impede their performance" (Al-Ajrafi, 2017: 155). Administrative empowerment is also known as "The relationship between risk-taking, daring and flexibility and the ability to persuade others, as well as using the scientific methodology to think and solve problems and this is one of the most creative behaviors of workers" (Radhi, 2010: 67).

Decentralization is defined as "The delegation of authorities/devolution of authorities for the lowest levels of positions, and it reflects the extent of the management's ability to distribute tasks within its authorities among its sub-ordinate personnel or other multiple entities across various administrative levels in a way that allows them to participate in the decision-making process, and to manage administrative issues of the organization" (Radhi, 2010, p. 15). Institutional performance is defined as "the extent to which the organization's goals are pursued and achieved" (Qalbo, 2015: 35). Accordingly, researchers find that the most important axes of the administrative empowerment process are the following: education, training and delegation of powers.

\section{Previous Studies/Literature}

A study conducted by (Al-Abdullah (2018: 16), aimed at exploring the dimensions of administrative empowerment and determine the degree of its implementation from the perspective of workers at HP in Saudi Arabia. The findings showed that there was a statistically significant effect from the perspective of HP employees in Saudi Arabia, relating to the "impact of devolution of authorities", "teamwork", "training" and "motivation" as the dimensions of empowering workers in its influence on improving professional performance. The researcher recommended that the company should strengthen communication ties among administrative various levels and maintain dependence on teamwork to accomplish required job tasks.

Al-Ajrafi's study (2017) aimed to identify the status of administrative empowerment of heads of faculty departments in Shaqra'a University in Dwami and its correlation with achieving job satisfaction. The findings revealed that there was a high and significant correlation between administrative empowerment and job satisfaction, and the researcher recommended give more attention to developing the capacities of heads of administrative departments to empower them to perform their job tasks successfully. 


\section{ENTREPRENEURSHIP AND SUSTAINABILITY ISSUES}

ISSN 2345-0282 (online) http://jssidoi.org/jesi/

2020 Volume 8 Number 2 (December)

http://doi.org/10.9770/jesi.2020.8.2(30)

Make your research more visible, join the Twitter account of ENTREPRENEURSHIP AND SUSTAINABILITY ISSUES: @Entrepr69728810

Al-Madadha (2016) made a study to discuss the effect of (empowerment of leadership, the environment of empowerment and psychological empowerment) and their impact on the creative and professional performance of employees. The researcher focused on detecting if there was any possible correlation between the integrative approach of empowerment and the creative performance of employees. The results indicated that there was a positive impact of the empowerment of leadership on the empowerment environment and psychological empowerment. Similarly, the empowerment environment has had a positive effect on psychological empowerment, and also the psychological empowerment has a positive impact on the creative performance, besides the importance of empowerment and its effects on the creative performance of employees.

Jiang, Flores, Leelawong, and Manz (2016) aimed to study the effect of the relationship between empowerment and team performance by focusing on the mechanisms of knowledge interchange and conflict within the group. The results showed that team empowerment can increase knowledge interchange and conflict within teams or groups work and that knowledge sharing facilitates team performance, while conflicts within a group weaken the public. (Al-Suhimat, 2016) aimed to analyze the impact of administrative empowerment on organizational creativity of workers in Mu'tah University, Jordan The researcher advised that the University of Mu'tah should pay attention to the concept of administrative empowerment and take policies and procedures that raise the level of awareness of this concept among employees by holding training courses for this purpose.

Abu Ruman, (2016) conducted a study to identify the impact of administrative empowerment on improving workers' creativity at Jordan Private Administration Institute (JPAI). The findings of the study indicated that there was a statistically significant impact of administrative empowerment (devolution of authorities, staff training, effective communication, and employees' motivation) on creativity improvement among employees in JPAI. The study recommended applying modern managerial concepts such as activating the principle of participation, working in groups, forming a team, and taking administrative decisions.

Shaqoura (2015), exploring the degree of the attention and interest given by secondary schools' principals in Gaza governorates to the requirements of administrative empowerment and their correlation with their achievement culture. The study concluded that the administrative requirements came in the highest ranks, followed by the organizational requirements and finally the logistic requirements. There were no statistically significant differences detected for the requirements of administrative empowerment that can be attributed to the variables of (gender, years of service/experience, and the educational qualification).

Aseeri and Al-Dhamen (2015) conducted a study aimed to explore the impact of job empowerment on improving their performance. The study revealed that there was a statistically significant effect of the dimensions of job empowerment (independence and freedom to act, sharing information, and management support) on improving employees' performance and the impact of the degree of performance improvement as a whole through the degree of job empowerment.

A study of Al-Qurashi (2014), aimed to identify the effect of empowering workers for the sake of improving job performance in health institutions in Taif. The results indicated that there were no statistically significant differences between the opinions of workers in health institutions in Taif, Saudi Arabia (including the physician, the nursing staff, and other workers) on the dimensions of (empowering employees, clarity of the purpose, ethics, recognition, and appreciation, teamwork, and participation). The findings also showed that there were no statistically significant differences from the perspective of workers in health institutions in the city of Ta'if relating to (clarity of purpose, participation, ethics, recognition, appreciation, and teamwork) as these include the dimensions of empowering workers and have an impact on improving their level of job performance. 


\section{ENTREPRENEURSHIP AND SUSTAINABILITY ISSUES}

ISSN 2345-0282 (online) http://jssidoi.org/jesi/

2020 Volume 8 Number 2 (December)

http://doi.org/10.9770/jesi.2020.8.2(30)

Make your research more visible, join the Twitter account of ENTREPRENEURSHIP AND SUSTAINABILITY ISSUES: @Entrepr69728810

Al-Ta'ani and Al-Suwai'i (2013) conducted a study aimed to identify administrative empowerment and its relationship to job satisfaction among principals of public schools in Dammam Governorate, Saudi Arabia. The findings indicated that there was a strong positive correlation between the degree of administrative empowerment and the degree of job satisfaction. The researchers recommended that job satisfaction should be given priority among other issues and receive more attention from the AAU of Education and give them more material and moral incentives for workers to maintain their job satisfaction.

Chen (2011) tried to explore the relationship between empowerment and employees' performance in the Malaysian auto industry and the effect of empowerment on employees' performance to determine which of the four empowerment dimensions had the greatest impact on employees' performance. Four dimensions were considered independent variables including (empowerment, competency, self-determination, and influence) whereas employee performance was the dependent variable. The results indicated that workers in the automotive industry think that empowerment strongly affects their performance and that there is a significant correlation between the dimensions of empowerment and employees' performance. They feel that their performance will greatly improve when they are independent, free, and have opportunities to influence the decision-making process in their work or their organizations.

Radhi (2010) study aimed to determine the relationship between administrative empowerment represented by its dimensions (delegation/devolution of authorities, teamwork, training, effective communication, and motivation) and the creativity of workers that includes (risk-taking, flexibility, persuasion, and scientific methodology in thinking and problem solving). The study revealed that there was a relationship between administrative empowerment and employees' creativity in addition to the existence of partial support for administrative empowerment correlation with most variables relating to employees' creativity. The researcher recommended that strategic leadership in the college should continue its policy in giving more attention to administrative empowerment to increase the level of workers' creativity in the areas where the response to administrative empowerment variables was reported.

Arieqat (2009) argues that empowerment is a transfer of responsibility and authority, and an invitation for workers to share the knowledge and information provided by the organization through its database, in problem analysis, and in decision-making, which lies within the decision-making authority. So, the subordinate will be responsible for the quality of what he/she decides to do, or what type of job to perform which leads to transferring the authority relatively, from the boss to the sub-ordinate employee.

Carter (2009) conducted a study to detect the relationship between organizations' behavior and the degree of employees' empowerment. The findings of the study showed that most workers were more productive if they were empowered by their management, and almost all organizations emphasized the importance of measuring employees' performance and boosting it. Also, many of these companies have realized that employees who participate in their activities actively contributed to supporting their managers 'decisions. Moreover, encouraging employees to shoulder more responsibilities enhances their productivity and contributes to raising morale and commitment, and empowerment contributes to promoting innovation, creativity, and motivation and instills common values and creates an environment for learning and achievement.

Emerson (2008), aimed to find out the reasons that make employees' empowerment an issue that is not merely an aphorism or a buzz word, but it is a process that achieves job satisfaction and enhances workers' performance and thus helps accomplish the company's goals. The study stressed that administrations should be keen to practice and 


\section{ENTREPRENEURSHIP AND SUSTAINABILITY ISSUES}

ISSN 2345-0282 (online) http://jssidoi.org/jesi/ 2020 Volume 8 Number 2 (December)

http://doi.org/10.9770/jesi.2020.8.2(30)

Make your research more visible, join the Twitter account of ENTREPRENEURSHIP AND SUSTAINABILITY ISSUES: @Entrepr69728810

encourage the method of empowering employees while keeping contact with employees and considering their views. The researcher also called to evaluate the means of mutual communication with their sub-ordinates. Employees should also have the freedom to express their views on the issues that concern them, and this makes them feel proud of the organization's appreciation of their efforts, ideas, and suggestions. As indicated by Rhadi (2010) who proved the direct relationship between creativity and empowering employees. The study population was targeted by selecting a random sample in order to ensure that there is no bias, and for the results to be faithfully expressive of the reality of administrative empowerment at Al-Ahliyya Amman University.

We hypothesize to test the effects of level of administrative empowerment and explaining its impact on the competency of institutional performance AAU. We test the level of administrative empowerment and explaining its impact on the competency of institutional performance AAU. To test our hypothesis. The data was collected from the (200) members working at AAU.

Table 1. Demographic aspects

\begin{tabular}{|c|c|c|c|c|c|}
\hline Gender & Male & Female & & & \\
\hline \multirow{3}{*}{ Age } & 79.5 & 20.5 & & & \\
\hline & Below 30 & $31-39$ & $40-45$ & $46-50$ & More than 51 \\
\hline & 23.0 & 21.5 & 31.5 & 18.5 & 5.5 \\
\hline \multirow[t]{2}{*}{ Education } & Bachelor & High Diploma & Master & $\mathrm{PhD}$ & \\
\hline & 50.5 & 23.0 & 19.5 & 7.0 & \\
\hline \multirow{2}{*}{ Experience } & $0-5$ & $6-10$ & $11-15$ & More than 16 & \\
\hline & 15.0 & 13.0 & 30.0 & 42.0 & \\
\hline Career Level & $\begin{array}{c}\text { Senior } \\
\text { management } \\
20.5\end{array}$ & $\begin{array}{l}\text { Middle management } \\
53.5\end{array}$ & $\begin{array}{c}\text { Executive } \\
\text { management } \\
26.0\end{array}$ & & \\
\hline \multirow[t]{2}{*}{ Job } & Director & Deputy Director & $\begin{array}{l}\text { Head of the } \\
\text { Department }\end{array}$ & Employee & \\
\hline & 18.0 & 23.0 & 33.0 & 26.0 & \\
\hline
\end{tabular}

Table 1 shows the demographic aspect of surveyed members of the AAU. Table 1 shows that most of management $79.5 \%$ were male and most of them $31.5 \%$ were from an age group of $40-45$ years. Education profile shows that most of the respondents $50.5 \%$ are carrying the bachelor's degree and $19.5 \%$ and $7 \%$ are also carrying the highest degree Master and $\mathrm{PhD}$ respectively. To test the level of administrative empowerment and explaining its impact on the competency of institutional performance, data was collected from 20.5\% Senior management and 53.5 Middle management and 26\% Executive management. Lastly, the experience distribution shows that $42 \%$ have more than 16 years' experience and $30 \%$ for the experience of $11-15$ years.

Table 2. Strength of relationship among the items in each construct

\begin{tabular}{l}
\hline Measurement items \\
\hline Delegation Authority (DA) \\
My direct manager in the AAU provides me with the necessary \\
information and knowledge related to my job tasks. $(D A 1)$ \\
The senior management of the AAU delegates some powers to the \\
directors of the departments therein. $(D A 2)$ \\
My direct manager in the AAU delegates the necessary powers to \\
perform the duties required of me. $(D A 3)$ \\
I am involved in decisions related to my work. $(D A 4)$ \\
My line manager provides adequate support and advice on my \\
delegated tasks. (DA5)
\end{tabular}


ENTREPRENEURSHIP AND SUSTAINABILITY ISSUES

ISSN 2345-0282 (online) http://jssidoi.org/jesi/

2020 Volume 8 Number 2 (December)

http://doi.org/10.9770/jesi.2020.8.2(30)

Make your research more visible, join the Twitter account of ENTREPRENEURSHIP AND SUSTAINABILITY ISSUES: @Entrepr69728810

AAU senior management works to give workers responsibility and decision-making. (DA6)

The AAU aims to involve all its employees for the success of the work. (DA7)

The senior management of the AAU focuses on the procedure whereby its employees are given the authority and authority to solve daily problems that arise during work. (DA8)

I have powers to correct deviations when they happen without referring to the immediate boss. (DA9)

The higher management of the AAU aims to give individuals greater authority in exercising oversight to increase their capabilities in the decision-making process. (DA10)

I have the freedom to perform the tasks entrusted to me and to discuss my ideas with the senior management of the AAU. (DA11)

\section{Independence (IN)}

$\alpha: 83.52 \quad t$-Value: 0.095

I have the opportunity to be proactive and independent in performing the required tasks. (IN1)

My line manager at the AAU trusts in my practical abilities to take on the responsibilities of my job. (IN2)

My position in the AAU provides opportunities to make independent decisions. (IN3)

The director of the department delegates sufficient powers to his assistants to accomplish their job duties. (IN4)

The line manager specifies the appropriate flexibility for subordinates to act in the performance of their job duties. (IN5)

The AAU is working to provide an appropriate degree of discretion to employees. (IN6)

The senior management of the AAU entrusts its employees with a degree of independence while holding them accountable for the results. (IN7)

The AAU is transferring enough powers to workers so that they can perform the tasks assigned to them freely. (IN8)

AAU's senior management encourages working individuals to take personal responsibility for developing the way they do their work. (IN9) My line manager encourages me to take responsibility by delegating authority to make decisions at the lowest level. (IN10)

Learning and Training (LT)

$\alpha: 86.76 \quad t$-Value: 8.971

4.1383

$\mathbf{0 . 7 1 6 9}$

Staff is trained to cope with developments in the AAU. (LT1)

The AAU is working hard to find new ways to train and develop business methods. (LT2)

The AAU continuously conducts training courses for its employees. (LT3)

Training courses focus on improving the skills and capabilities of workers in the AAU. (LT4)

The results of the training courses are evaluated at the end of each training program. (LT5)

The period specified for the plans corresponds to the topics raised in the training program. (LT6)

The training material is prepared in light of the needs of the trainees. (LT7)

The AAU uses modern training methods to implement training programs. (LT8)

The AAU senior management adopts a clear training plan. (LT9)

The AAU provides various training courses to develop the skills of its employees. (LT10) 
ENTREPRENEURSHIP AND SUSTAINABILITY ISSUES

ISSN 2345-0282 (online) http://jssidoi.org/jesi/

2020 Volume 8 Number 2 (December)

http://doi.org/10.9770/jesi.2020.8.2(30)

Make your research more visible, join the Twitter account of ENTREPRENEURSHIP AND SUSTAINABILITY ISSUES: @Entrepr69728810

AAU employees have opportunities to learn and acquire new tasks in their field of work. (LT11)

Training helps to provide employee self-motivation to increase efficiency and improve productivity. (LT12)

Training plans are designed to address business problems and avoid any future imbalances. (LT13)

\section{Institutional Performance (IP)}

$\alpha: 77.82 \quad t$-Value: 1.066

AAU employees perform the tasks assigned to them according to the required quality standards. (IPI)

Workers complete job tasks on time. (IP2)

The AAU is keen to provide specific performance indicators for workers. (IP3)

AAU employees can initiate and innovate. (IP4)

The relationship of employees with their superiors is characterized by friendliness and harmony. (IP5)

Workers are keen to use the capabilities and resources available by the AAU efficiently and effectively. (IP6)

The AAU seeks to fulfill its obligations to society through service excellence. (IP7)

The AAU is keen to develop its financial services in line with its social responsibilities. (IP8)

The AAU seeks to simplify the work procedures. (IP9)

The AAU is investing a lot of money in the rehabilitation and development of its human resources. (IP10)

The AAU routinely develops its administrative procedures and technical practice. (IP11)

The AAU possesses distinguished administrative competencies in the field of its main services. (IP12)

The AAU carries out an assessment of the needs of the beneficiaries of its services provided periodically. (IP13)

The AAU provides its services in response to the needs of the public. (IP14)

Cronbach Alpha test is applied to test the strength of the relationship among the items in each construct. We find that all dependent and independent variables have Cronbach Alpha at least more than 0.80 except the Institutional Performance (IP) which has Cronbach Alpha 0.77.82. Moreover, our objective is to test the level of administrative empowerment and explaining its impact on the competency of institutional performance AAU. Cronbach Alpha value shows an excellent strength of the relationship. Overall, all the constructs are shown the validity to proceed for further analyses (Table 2).

Table 3. Regression dependent variable is the effectiveness of administrative decisions

\begin{tabular}{|c|c|c|c|c|}
\hline Variable & Coeff & SE & $\mathbf{t}$ & $\mathbf{P}$ \\
\hline Delegation Authority & $-8.84 \mathrm{E}-02$ & 0.088 & -1.001 & 0.005 \\
\hline Independence & 9.954E-03 & 0.104 & 0.095 & 0.001 \\
\hline Learning and training & 1.014 & 0.113 & 8.971 & 0.000 \\
\hline Institutional Performance & 0.324 & 0.304 & 1.066 & 0.000 \\
\hline The goodness of Fit (F-value) & 70.049 & & & 0.000 \\
\hline $\mathrm{R} 2$ & 0.517 & & & \\
\hline
\end{tabular}


ENTREPRENEURSHIP AND SUSTAINABILITY ISSUES

ISSN 2345-0282 (online) http://jssidoi.org/jesi/

2020 Volume 8 Number 2 (December)

http://doi.org/10.9770/jesi.2020.8.2(30)

Make your research more visible, join the Twitter account of ENTREPRENEURSHIP AND SUSTAINABILITY ISSUES: @Entrepr69728810

The regression's result shows (Table 3) that the effects of (DA), (IN), and (LT) on the (IP) of the AAU are found positive and significant. So, the AAU efforts for (DA), (IN), and (LT) are found very helpful in improving the (IP) of the AAU. In comparison, the (DA) has the greatest effect on the (IP) of the AAU. It means that the AAU inputs in the (DA) are important for the (IP). However, the magnitude of the effect of the (IN) and (LT), is also found nearby to the magnitude of the (DA). It means that (IN) and (LT), of the AAU, also does matter equally in the impact of the level of administrative empowerment involving achieving the higher (IP).

\section{Conclusions \& Recommendations}

1. Focus on training workers at AAU to practice job empowerment, through implementing action plans for development purposes, develop annual plans for training, use effective methods such as lectures, and encourage workers to participate in training programs.

2. Adopt a strategy that realizes the application of modern management concepts in the AAU such as job empowerment, total quality management, and teamwork.

3. Grant rewards for the AAU for the working teams and involve workers in specialized programs on job empowerment.

4. Delegate authorities to employees at the AAU in a balanced manner that is relevant to their responsibilities.

5. Allow workers to participate in the process of decision-making and decision-taking at the AAU.

6. Develop the administrative skills of workers in AAU through raising their knowledge and awareness of modern management concepts.

7. Develop work procedures at the AAU to meet the requirements of job empowerment.

8. Assign a box to receive complaints and proposals from workers at the AAU to express their views and suggestions about the degree of the AAU senior management implementation of administrative empowerment, to what extent it delegates authorities to employees and enables them to behave independently.

\section{Limitations and Future Recommendations}

The conclusions derived from the findings of this study need to consider the following limitations:

1) This study was focused on four dimensions of administrative empowerment (delegating powers/devolution of authorities, independence, learning, and training) and did not include other factors that can influence institutional performance, such as knowledge sharing, team empowerment, and power distance.

2) the study questionnaire was distributed randomly to 200 respondents in general, it would give better results if we increase the number of respondents and focus more on the targeted respondents whether they are undergraduate or employed at AAU.

3) it is important to figure out that, when answering the questionnaire, respondents revealed their subjective perceptions which may limit the objectivity of the survey results.

4) the study findings are related to the specific country "Jordan" in which the research was conducted, the results may have limited generalizability a broad, therefore, more studies need to be considered in other regions on different sectors. 


\section{ENTREPRENEURSHIP AND SUSTAINABILITY ISSUES}

ISSN 2345-0282 (online) http://jssidoi.org/jesi/

2020 Volume 8 Number 2 (December)

http://doi.org/10.9770/jesi.2020.8.2(30)

Make your research more visible, join the Twitter account of ENTREPRENEURSHIP AND SUSTAINABILITY ISSUES: @Entrepr69728810

\section{References}

Abu-Ruman, N. (2016). Impact of Administrative Empowerment on Creativity Improvement among the Workers of Jordanian Public Administration Institute. International Journal of Business and Social Science, 7(1), 182-190.

Al- Dhamen, Rula (2015). Impact of the Job Empowerment Implementation on Improving Employees' Performance: An applied study on the supervisors of the Education Department, Journal of Financial and Commercial Research, Faculty of Commerce, Port Sa'eed University, 1, 282-303.

Al-Abdullah, Ma'en Ahmad (2018). Empowerment Impact on Job Performance: A study on HP Company in Saudi Arabia, unpublished Master Thesis, Syrian Virtual University.

Al-Ajrafi, Falah, (2017). Administrative empowerment and its correlation with achieving job satisfaction, was conducted on the heads of the departments at the faculties of Shaqra'a University in Al-Dwadmi, Saudi Arabia. Specialized Educational International Journal, 6(9), $152-167$.

Al-Madadha, A. (2016). The influence of an integrative approach of empowerment on the creative performance for employees (Doctoral dissertation, Cardiff Metropolitan University).

Al-Omari, Z., Alomari, K \& Aljawarneh, N. (2020). The role of empowerment in improving internal process, customer satisfaction, learning and growth. Management Science Letters, 10(4), 841-848. http://doi.org/10.5267/j.msl.2019.10.013

Al-Qurashi, Saleem \& Al Hmeidan, Abdullah (2014). Impact of Staff Empowerment on Job Performance Improvement: Applied study on the health services sector in the city of Ta'if", Master Thesis, Faculty of Commerce, Port Sa'eed University, Egypt.

Al-Suhimat, S. (2016). Impact of Administrative Empowerment on Organizational Creativity: An Analytical Study from the Perspective of Employees at the University of Mu'tah in Jordan. Imperial Journal of Interdisciplinary Research (IJIR), 2(10), $70-78$.

Al-Ta'ani and Al-Suwai', Hasan Ahmad \& Omar Sultan (2013). Administrative Empowerment and its Relationship to Job Satisfaction among Principals of Public Schools in Dammam, Saudi Arabia. Studies of Educational Sciences, 40(1), 305-327.

Areiqat, Ahmad \& Naji, Bayan. (2016). The Role of Employee's Empowerment Strategy in Improving Organization's Effectiveness. Dirasat: Administrative Sciences, 161(3988), 1-16.

Areiqat, Ahmad \& Zamil, Ahmad. (2011). The role of empowerment in crisis management in business organizations. Asian Journal of Business Management, 3(3), 188-195. Maxwell Science Publishing.

Areiqat, Ahmad Yousef. (2010). Role of Empowerment of Crisis Management in Business Organizations. The Seventh International Scientific Conference. Zerqa Private University.

Aseeri and Al-Dhamen. (2015). The Impact of the Job Empowerment Implementation on Improving Employees' Performance: An applied study on the supervisors of the Education Department at Aseer region, Yemen. Unpublished Master thesis.

Carter, J. T. (2009). Managers Empowering Employees. American Journal of Economics and Business Administration, 1(2), 41-46. https://doi.org/10.3844/ajebasp.2009.41.46

Chen, K. P. (2011). A Study on the Impact of Empowerment on Employee in the Automotive Industry in Malaysia. Unpublished Thesis. Open University Malaysia.

Emerson, A. (2008). Why Employee Empowerment should be more than just a Buzz Word at Your CU. Credit Union Journal, 81.

Khalayleh, Wea'am Aref \& Masa'deh, Ra'ed \& Al-Lozi, Musa. (2017). Administrative Empowerment and its Role on the Work Teams Performance: A Literature Review. Journal of Social Sciences (COES\&RJ-JSS), 6(4), 851-868, October. 
ENTREPRENEURSHIP AND SUSTAINABILITY ISSUES

ISSN 2345-0282 (online) http://jssidoi.org/jesi/

2020 Volume 8 Number 2 (December)

http://doi.org/10.9770/jesi.2020.8.2(30)

Make your research more visible, join the Twitter account of ENTREPRENEURSHIP AND SUSTAINABILITY ISSUES: @Entrepr69728810

Qalbo, Husniyyah, (2015). Role of Knowledge Management in Institutional Performance, unpublished Master thesis, Mohammad Khudeir University, Baskarah.

Radhy, Jawad Muhsen, (2010). Administrative Empowerment and its Relationship to Staff Creativity, a field study on a sample of employees at the Faculty of Management and Economics, Al- Qadisiyah Journal for Administrative and Economic Sciences, 12(1), 62-84.

Shaqoura, Mohammad. (2015). The requirements of Administrative Empowerment of the Principals of Secondary Schools at the Governorates of Gaza and their Correlation with their Achievement Culture. Master thesis, Faculty of Education, Al-Azhar University, Gaza, Palestine.

Thomas, Ammu, \& Priyanka, Jenifer (2014). Study of Decentralization in Construction Companies (Kerala), International Journal of Civil Engineering and Technology (Ijciet), 5(12), 235-238.

Uddin, Nasir. (2017). Empowerment through Decentralization: Conceptions, Contrivances and Connections. Dynamics of Public Administration, 34(1), 86-101. https://doi.org/10.5958/0976-0733.2017.00008.6

Xueting, Jiang Hector R., Leelawong, Flores Ronrapee, \& Manz, Charles C. (2016). The effect of team empowerment on team performance. International Journal of Conflict Management, 27(1), 62 - 87, http://dx.doi.org/10.1108/IJCMA-07-2014-0048

Ahmad Ismail Al MAANI is the Associate Professor of Business Administration and Director of the Department of Higher Education, Modern College of Business \& Science, Oman.

ORCID ID: 0000-0001-5122-749X

Ahmad Al ADWAN is the Associate Professor and Head of Marketing Department, Business School, Al-Ahliyya Amman University, Amman, Jordan. ORCID ID: 0000-0003-0451-0182

Ahmad Yousef AREIQAT is the Professor, Department of Business Administration, Business School, Al-Ahliyya Amman University. Amman, Jordan.

ORCID ID: 0000-0003-0379-7409

Ahmad. M.A. ZAMIL is the Associate Professor, Department of Marketing, College of Business Administration, Prince Sattam bin Abdulaziz University, Saudi Arabia.

ORCID ID: 0000-0002-3700-8458

Anas A. SALAMEH is the Assistant Professor, Department of Management Information Systems, College of Business Administration, Prince Sattam bin Abdulaziz University, Saudi Arabia.

ORCID ID: 0000-0002-4694-3771

Copyright (C) 2020 by author(s) and VsI Entrepreneurship and Sustainability Center

This work is licensed under the Creative Commons Attribution International License (CC BY).

http://creativecommons.org/licenses/by/4.0/

cC) (†) Open Access 